\title{
Pengaruh Need for Achievement Terhadap Job Performance dengan Budgetary Participation sebagai Variabel Intervening
}

\author{
Yusar Sagara ${ }^{1}$, Indah Permatasari ${ }^{2}$, Roebiandini Soemantri ${ }^{3}$ \\ 1,2 Universitas Islam Negeri Syarif Hidayatullah, Jakarta, Indonesia \\ ${ }^{3}$ Universitas Padjadjaran, Bandung, Indonesia
}

\section{INFO ARTIKEL \\ JEL Classification :}

$\mathrm{J} 24, \mathrm{~L} 21$

\section{Keywords :}

need for achievement, budgetary participation, job perfomance

\begin{abstract}
Employee performance is very important to determine success and failure in achieving organizational goals. But the high performance of employees depends on motivation and a supportive work environment. So that in this study aims to examine the relationship between need for achievement which is a motivation for employees to participate in the budget so that it indirectly affects the performance improvement at the Planning and Finance Bureau of the Secretariat General of the Ministry of Finance. The sample selection technique used in this study was purposive sampling. 72 respondents were obtained as samples. Data analysis and hypothesis testing methods are used using the Structural Equation Model (SEM) with the help of Lisrel 8.80. Normality test is carried out before using Structural Equation Model (SEM) analysis. The results of this study indicate that directly or indirectly the need for achievement has a positive and significant effect on job performance through budget participation. This study has implications for the design of an effective budgeting process by involving the concept of motivation which creates a responsibility in achieving the goals that have been designed.
\end{abstract}

\begin{abstract}
ABSTRAK
Kinerja pegawai sangat penting untuk menentukan keberhasilan dan kegagalan dalam pencapaian tujuan organisasi. Namun tingginya kinerja pegawai tergantung dari motivasi dan lingkungan kerja yang mendukung. Sehingga dalam penelitian ini bertujuan mengkaji keterkaitan antara need for achievement yang menjadi suatu motivasi pegawai dalam melakukan partisipasi anggaran sehingga secara tidak langsung berdampak pada peningkatan kinerja pada Biro Perencanaan dan Keuangan Sekretariat Jenderal Kementrian Keuangan. Teknik pemilihan sampel yang digunakan dalam penelitian ini adalah purposive sampling. Sebesar 72 responden diperoleh sebagai sampel. Metode analisis data dan pengujian hipotesis yang digunakan menggunakan Structural Equation Model (SEM) dengan bantuan Lisrel 8.80. Uji normalitas dilakukan sebelum menggunakan analisis Structural Equation Model (SEM). Hasil penelitian ini menunjukkan bahwa secara langsung maupun tidak langsung need for achievement berpengaruh positif dan signifikan terhadap job performance melalui budgetay participation. Studi ini memiliki implikasi untuk desain proses penganggaran yang efektif dengan melibatkan konsep motivasi
\end{abstract}

*Email Korespondensi: ${ }^{1}$ yusar.sagara@uinjkt.ac.id, ${ }^{2}$ indahpermatas31@gmail.com 
yang meciptakan sebuah tanggung jawab dalam mencapai tujuan yang telah dirancang.

\section{Pendahuluan}

Job performance merupakan aktivitas seseorang dapat menyelesaikan tugas atau pekerjaan yang dimiliki dengan sukses. Dalam pandangan organ-isasi pegawai dianggap sebagai suatu aset yang berharga, karena pegawai dengan kinerja yang tinggi dapat mengarahkan pada kesuksesan organisasi dan bagi pegawai dengan tercapainya tujuan organisasi atas kinerjanya menimbulkan efek kepuasan tersendiri.

Keberhasilan atau kegagalan utama suatu organisasi sangat ditentukan oleh kinerja pegawai mereka. Namun masalah muncul ketika pegawai memandang bahwa organisasi mereka telah sukses, sehingga tidak diperlukannya perbaikan lebih lanjut dalam kinerjanya. Hal tersebut harus ditanggulangi dan ditangani karena dapat menghasilkan kompetensi yang kurang berkembang dan mengarah pada ketidakefektifan organisasi.

Dengan demikian diperlukanlah sebuah rencana bagi organisasi. Ketika rencana ditransformasikan menjadi kualitatif maka menjadi ang-garan. Anggaran digunakan rencana organisasi dalam suatu periode serta standar yang dapat dibandingkan dan diukur terhadap kinerja aktual-nya.

Anggaran berfungsi untuk mengalokasikan sumberdaya di antara kebutuhan untuk mencapai tujuan serta mengendalikan perilaku dan memban-tu keputusan yang lebih baik untuk mencapai suatu tujuan.

Dengan kata lain, anggaran digunakan untuk memetakan pergerakan organisasi selama rentang waktu tertentu sehingga tetap berada didalam batasan dan tercapainya tujuan yang di inginkan. Tanpa rencana insentif, individu tidak akan siap untuk memenuhi tujuan mereka (Myint et.al, 2019).

Bedasarkan Undang-Undang Nomor 17 Tahun 2003 tentang Keuangan Negara menjelaskan sistem penganggaran di Indonesia yang semula tradisional budgeting menjadi performance based budgeting. Tolak ukur keberhasilan sistem ini terletak pada hasil kinerja atau output yang dicapai dari hasil ang-garan dengan menggunakan dana secara efisien. Output yang baik memberikan kemaslahatan yang baik, sebaliknya output yang kurang baik mencerminkan tidak optimalnya hasil kinerja akibat belanja yang dikeluarkan tidak efisien.

Oleh karna itu diperlukan sebuah partisipasi aktif para pegawai dari level atas sampai bawahan dalam merancang target anggaran dan target kiner-ja untuk mencapai sebuah keputusan yang realistis dan sejalan dengan tujuan organisasi. Karena pada dasarnya pegawai bawahan lebih memiliki infor-masi yang lebih banyak dari pada atasan mengenai apa yang dibutuhkan dan implikasinya. Hal tersebut dapat mengurangi resiko alokasi belanja yang tidak efisien.

Ketika suatu tujuan dirancang dengan melibat-kan pegawai bawahan akan membuat aspirasi mereka dihargai, kemudian akan membentuk tanggung jawab dan komitmen mencapai tujuan tersebut dengan meningkatkan kinerja mereka. Hal tersebut dapat dijelaskan karena pada dasarnya partisipasi merupakan keterlibatan mental dan emosional, memotivasi mereka untuk memberi kontribusi dalam pencapaian tujuan kelompok dan menerima tanggung jawab untuk pencapaian tujuan tersebut.

Dari perspektif ini partisipasi mengarah pada motivasi, komitmen, dan keputusan berkualitas yang lebih tinggi dan karenanya kinerja menjadi lebih baik. Partisipasi anggaran bisa lebih efektif ketika seseorang memiliki kebutuhan untuk berpres-tasi yang berdampak pada peningkatan kinerjanya. Karena pada dasarnya seseorang yang memiliki kebutuhan untuk berprestasi memiliki keinginan kuat untuk berkompetensi dengan suatu standar keunggulan dimana akan berkinerja lebih baik dari orang lain dan mendapatkan sebuah feedback atas hasil upaya mereka.

Melalui partisipasi anggaran pegawai yang memiliki kebutuhan untuk berprestasi yang tinggi cenderung berpartisipasi lebih aktif dibandingkan pegawai yang memiliki kebutuhan untuk berpres-tasi yang rendah. Hal tersebut dikarenakan partisipasi membantu pegawai mendapatkan in-formasi 
yang relavan terhadap pekerjaan dan memastikan tujuan tersebut dapat dicapai sesuai dengan kemampuan mereka untuk mendapatkan pengakuan atau feedback yang baik.

Namun partisipasi anggaran tidak dapat meningkatkan kinerja jika motivasi yang dimiliki pegawai rendah. Dimana tidak mengeluarkan ide yang dimiliki akibat dalam proses penyusunan anggaran pegawai hanya sebatas ikut merencanakan untuk kepentingan persetujuan organisasi (Ernawati, 2017). Hal tersebut dapat disebabkan pegawai bawahan merasa pandangan mereka memiliki pengaruh yang rendah atau bahkan tidak memiliki pengaruh sama sekali. Karena atasan lebih mendominasi dalam penyusunan anggaran.

Dengan demikian pegawai tidak memiliki mo-tivasi dalam mengembangkan menyampaikan ide kreatif yang dimiliki, yang menciptakan keadaan underparticipation atas kurang memperoleh kesempatan dari apa yang mereka inginkan yang menciptakan ketidakpuasan pada proses pengambilan keputusan. Akibatnya pegawai kurang memiliki komitmen dan bertanggung jawab atas tujuan yang dibuat, sehingga pegawai tidak termotivasi dalam meningkatkan kinerja untuk mencapai tujuan organisasi.

Hasil yang tidak konsisten mengenai partisipasi anggaran ditunjukan pada beberapa penelitian terdahulu. Berdasarkan penelitian Her-nanda \& Mukzam (2018), Lestariningsih (2017), dan Utomo et.al (2017) menunjukan need for achievement berpengaruh positif dan signifikan terhadap job performance. Namun Aziti (2019) tidak menunjukan pengaruh yang signifikan. Djalil et.al (2017), dan Wiguna (2017) menunjukan need for achievement se-bagai konsep motivasi berpengaruh positif terhadap budgetary participation. Namun Ernawati (2017) tid-ak dapat membuktikannya. Myint et.al (2019), Kara-koc \& Ozer (2016), dan Wiguna et.al (2017) menunjukan budgetary participation berpengaruh positif terhadap job performance. Sedangkan Andison \& Augustin (2017) \& Ernawati (2017) tidak menunjukan pengaruh partisipasi anggaran dalam meningkatkan kinerja.

Penelitian ini dilakukan berdasarkan fenomena penelitan terdahulu yang tidak konsisten. Penelitian ini bertujuan untuk meneliti lebih lanjut apakah konsep need for achievement dapat menjadi motivasi yang mempengaruhi partisipasi anggaran untuk berkontribusi lebih aktif dan mendapatkan informa-si yang relavan terkait pekerjaan dalam mendapatkan pengakuan dan feedback yang baik, secara tidak langsung akan mengahasilkan kinerja tinggi untuk mencapai tujuan yang ditetapkan dalam proses penganggaran.

\section{Telaah Teori dan Pengembangan Hipotesis}

\section{Teori Penetapan Tujuan}

Teori ini menjelaskan penetapan tujuan tertentu akan menghasilkan sebuah motivasi dan kinerja lebih tinggi. Goals akan menginformasikan individu untuk memcapai tingkat kerja tertentu, agar mereka mengarahkan dan mengevaluasi tindakan mereka, sementara feedback kinerja memungkinkan individu untuk melacak seberapa baik dirinya dalam mencapai tujuan deperti upaya, arahan atau strategi yang dilakukan (Mensah \& Tawiah, 2016).

Dengan menentukan sebuah tujuan maka individu akan memikirkan masa depan yang lebih baik sehingga dapat memotivasi mereka untuk mencapai harapan tersebut (Rosada et.al, 2018).

Oleh karena itu, goal setting theory dapat menjelaskan perencanaan dan kinerja individu. Dalam teori ini bahwa penetapan tujuan oleh individu yang terlibat akan memiliki rasa tanggung jawab dapat mempengaruhi kinerja karena merasa dituntut untuk mencapai tujuan yang telah dirancang.

Kinerja yang dilakukan pegawai sebagai suatu proses pencapaian tujuanya. Selain itu, partisipasi anggaran dan motivasi need for achievement sebagai faktor penentunya. Maka, keberhasilan pencapaian tujuan lebih tinggi jika faktor penentu tersebut tinggi.

\section{Teori Harapan}

Teori harapan menjelaskan individu akan giat bekerja tergantung dari harapan yang di inginkan yang memberi mereka sebuah kekuatan motivasi (Husniyawati \& Wulandari, 2016).

Dalam teori harapan seseorang akan termotivasi ditentukan oleh expectancy, instrumentality, dan valance. Expectancy 
adalah upaya tertentu akan mengarahkan kinerja yang spesifik. Instrumentality adalah keyakinan akan menerima rewards atas hasil kinerja yang dilakukan. Sedangkan valance adalah sejauh mana seorang individu memiliki preferensi untuk hasil yang diberikan (Lloyd \& Mertens, 2018).

Teori tersebut dapat mengungkapkan bahwa pegawai yang memiliki need for achievement tinggi memiliki harapan sebuah penghargaan yang mereka terima dari upaya kinerja mereka dalam mencapai tujuan organisasi yang telah ditetapkan pada proses penyusunan anggaran.

\section{Teori Motivasi Berprestasi}

Teori motivasi berprestasi dapat disebut juga sebagai teori kebutuhan yang diperoleh atau teori kebutuhan yang dipelajari (Acquah, 2017). Ketika seseorang memiliki kebutuhan yang kuat maka timbul sebuah motivasi untuk berperilaku yang mengarah ke pencapaian kepuasan kebutuhan.

Setiap individu memiliki motivasi berprestasi yang berbeda, hal ini didasari sebagaian orang memiliki kualitas tingkatan motivasi berprestasi tinggi dan sebagian lainnya tidak. Untuk dapat memahami perilaku manusia dan bagaimana mereka termotivasi, maka terlebih dahulu harus memahami kebutuhan dan kecenderungannya.

Pada dasarnya teori ini berupaya menerangkan perilaku dan kinerja dapat dipengaruhi oleh kebutuhan seseorang. Kebutuhan dalam teori ini terbagi atas kebutuhaan prestasi, kebutuhan kekuasaan dan kebutuhan afiliasi (affiliation) (Hernanda \& Mukzam, 2018).

\section{Budgetary Participation}

Partisipasi anggaran adalah kegiatan penyusunan anggaran secara bersama-sama dengan melibatkan bawahan dan atasan dengan harapan target dapat dicapai (Ernawati, 2017).

Partisipasi dalam penyusunan anggaran sangat penting karena tujuan akan lebih mudah tercapai jika anggota organisasi terlibat diberi kesempatan berpartisipasi dalam menyusun tujuan yang direncanakan (Wiguna et.al, 2017).
Penyusunan anggaran harus melibatkan semua tingkatan organisasi untuk berpartisipasi dalam proses penganggaan karena atasan biasanya kurang mengetahui kegiatan yang dibutuhkan pada tingkat bawah (Meirina \& Afdallidin, 2018).

\section{Need for achievement}

Kebutuhan berprestasi yaitu sebuah keinginan melakukan pekerjaan yang diberikan untuk lebih baik dari pada sebelumnya (Hernanda \& Mukzam, 2018). Menurut Chong \& Khudzir (2018) kebutuhan untuk berprestasi yaitu keinginan atau kebutuhan yang kuat untuk mempertahankan penerimaan penghargaan mereka, pengakuan, reputasi dan karena itu termotivasi untuk bertindak dengan cara yang lebih dalam pencapaiannya.

Dengan adanya suatu kebutuahan prestasi maka akan mengarah pada perilaku tertentu terkait pekerjaan untuk pencapaian prestasi tertentu yang diinginkan (Murgijanto, 2017).

Individu yang memiliki tingkat kebutuhan berprestasi tinggi umumnya memiliki tujuan pekerjaan yang sesuai dengan kemampuan mereka. Mereka juga fleksibel dalam mencari informasi secara terperinci untuk membantu mereka dalam mengejar keunggulan.

\section{Job Performance}

Kinerja bagi individu sangat penting karena merupakan sebuah hasil prestasi individu dalam bekerja sesuai dengan visi, misi, dan sasaran dari tujuan organisasi (Ernawati, 2017). Menurut Omari \& Okasheh (2017) mendefinisikan performance merupakan sebuah hasil kerja kelompok atau individu suatu organisasi dalam periode tertentu untuk melihat seberapa baik mereka bekerja mencapai kualifikasi dalam pencapaian tujuan organisasi.

Menurut Kar \& Mishra (2016) job performance dapat dilihat sebagai aktivitas dimana seseorang dapat melaksanakan suatu tugas yang diberikan dengan baik, mematuhi batasan dengan memanfaatkan sumberdaya yang disediakan secara wajar. Job performance merupakan hasil dari tiga faktor dalam bekerja sama yaitu keterampilan, upaya, dan kondisi kerja. Keterampilan yang dibawa individu dalam pekerjaannya yang meliputi pengetahuan, kemampuan, dan 
kompetensi; upaya merupakan tingkat motivasi yang dilakukan individu dalam bekerja; dan kondisi kerja adalah tingkat akomodasi kondisi dalam memfasilitasi produktivitas pegawai.

\section{Pengaruh Need for Achievement terhadap Job Performance}

Kebutuhan berprestasi merupakan keinginan individu untuk lebih baik dan efektif dalam menyelesaikan masalah dan tugas yang sulit dari pada orang lain. Teori motivasi prestasi menjelaskan bahwa motivasi dan kinerja bervariasi berdasarkan tingkat kebutuhan seseorang untuk berprestasi.

Mereka cenderung mengambil resiko moderat, mengekplorasi cara baru dalam melakukan sesuatu, dan berkomitmen yang dapat membawa ide kreatif dan inovatif ke strategi organisasi sehingga secara tidak langsung berkinerja lebih tinggi dan menghasilkan kerja yang baik. Dikarenakan mereka memiliki semangat untuk berupaya sekuat tenaga berusaha mencapai apa yang di inginkan sehingga berdampak pada peningkatan kinerjanya. Namun upaya keras belum dapat dipastikan menghasilkan kinerja yang diharapkan jika tidak didukung organisasi.

Penelitian terdahulu mengatakan bahwa need for achievement berpengaruh positif terhadap job performance oleh Hernanda \& Mukzam (2018), Lestariningsih (2017) dan Utomo et.al (2017). Berdasarkan uraian diatas, maka dapat dikembangkan hipotesis sebagai berikut:

H1: Need for achievement positif terhadap Job Performance

\section{Pengaruh Need for achievement terhadap Budgetary participation}

Individu dengan kebutuhan untuk berprestasi akan berpartisipasi dalam pengaturan anggaran untuk mendapatkan informasi yang relavan terkait pekerjaan yang mungkin membantu mereka dalam menetapkan tujuan yang tepat.

Mereka juga cenderung mencari kontrol yang lebih besar atas lingkungan kerja mereka untuk memaksimalkan probabilitas dalam mencapai tujuan mereka, dan partisipasi anggaran memfasilitasi pencapaian kontrol tersebut untuk memastikan bahwa tujuan yang disusun dapat dicapai sesuai dengan kemampuan yang dimiliki dalam mendapatkan suatu penghargaan atas hasil kerjanya.

Penelitian terdahulu mengatakan bahwa suatu konsep motivasi kerja dalam memeuhi need for achievement berpengaruh positif terhadap budgetary participation oleh Djalil (2017) \& Wiguna (2017). Namun penelitian yang dilakukan oleh Ernawati (2017) tidak dapat membuktikannya. Berdasarkan uraian diatas, maka dapat dikembangkan hipotesis sebagai berikut:

H2: Need for achievement berpengaruh positif terhadap Budgetary participation

\section{Pengaruh Budgetary participation terhadap Job performance}

Budgetary participation sebagai suatu proses dimana pegawai terlibat dan mempengaruhi pengaturan target anggaran. Pada dasarnya pegawai bawahan senang bekerja atas keterlibatan mereka dalam penyusunan anggaran dan lebih mengetahui secara spesifik tujuan anggaran, dibandingkan dengan anggaran yang sudah ditetapkan oleh atasan.

Hal tersebut dikarenakan mereka diberi kesempatan untuk mengumpulkan dan bertukar informasi yang akan membentuk sebuah kepuasan atas suatu keputusan yang ditetapkan dalam penganggaran.

Sehingga timbul rasa tanggung jawab atas keterlibatan mereka untuk mencapai keputusan tersebut yang secara tidak langsung akan meningkatkan kinerja mereka. Oleh sebab itu adanya partisipasi dalam penganggaran menjadi faktor untuk membentuk komitmen pada tercapainya tujuan anggaran, sehingga job performance individu meningkat untuk mencapai tujuan tersebut.

Penelitian terdahulu mengatakan bahwa budgetary participation berpengaruh positif terhadap job performance oleh Myint et. Al (2019), Karakoc \& Ozer (2016) \& Wiguna et.al (2017). Namun penelitian yang dilakukan oleh Andison \& Augustin (2017) budgetary participation tidak berpengaruh terhadap job performance. Berdasarkan uraian diatas, maka dapat dikembangkan hipotesis sebagai berikut: 
H3: Budgetary participation berpengaruh positif terhadap job performance

\section{Pengaruh need for achievement tehadap job performance dengan budgetary participation sebagai variable intervening}

Dalam konteks penetapan anggaran, tingginya kebutuhan untuk berprestasi para para pegawai memungkinkan untuk menetapkan target anggaran yang mudah dicapai untuk memastikan bahwa mereka dapat menerima lebih banyak penghargaan dan pengakuan atas pencapaian mereka.

Mereka mencari proses organisasi seperti penganggaran partisipatif karena memiliki dua alasan. Pertama, karena termotivasi untuk menciptakan nasib mereka sendiri. Kedua, memperoleh informasi yang terkait dengan pekerjaan yang dapat membantu mereka untuk menetapkan tujuan yang tepat. Hal tersebut dilakukan untuk memastikan tujuan organisasi dapat dicapai untuk memenuhi kebutuhannya dalam mendapatkan suatu pengakuan atas upaya kinerja mereka yang lebih unggul dibanding orang lain. Secara tidak langsung mereka termotivasi untuk meningkatkan kinerjanya.

Berdasarkan uraian diatas, maka dapat dikembangkan hipotesis sebagai berikut:

H4: Need for achievement berpengaruh positif terhadap job performance melalui budgetary participation

\section{Metode Penelitian}

Penelitian ini menggunakan tiga variabel, yaitu variabel independen (X) need for achievement, variabel intervening (Y) budgetary participation dan variabel dependen (Z) job performance. Populasi penelitian ini adalah pegawai Biro Perencanaan dan Keuangan Sekretariat Jenderal Kementrian Keuangan. Teknik pengambilan sampel dalam penelitian ini menggunakan purposive sampling dengan kriteria pegawai yang pernah terlibat dalam proses penyusunan anggaran.

Penelitian ini menggunakan metode SEM untuk pengolahan data dengan bantuan Lisrel 8.80 , maka untuk menentukan jumlah sampel minimal 100-200 responden atau 5 observasi untuk setiap estimasi parameter, dalam penelitian ini jumlah item kuesioner sebanyak
19 butir, dengan demikian sampel yang diperlukan sekurang-kurangnya sebanyak 19 x $5=95$.

Metode pengumpulan data yang digunakan dalam penelitian ini adalah pengumpulan data primer. Dimana peneliti mengumpulkan data secara langsung ke sumber pertama atau tempat objek dengan mengirimkan secara langsung kuesioner ke Biro Perencanaan dan Keuangan Sekretariat Jendral Kementerian Keuangan RI untuk mengukur persepsi responden terhadap pengaruh need for achievement terhadap job performance melalui budgetary participation.

\section{Hasil Penelitian dan Pembahasan}

Jumlah sampel yang didapatkan sebanyak 72 responden. Dikarenakan dalam penelitian ini data yang diperoleh belum dianggap memenuhi persyaratan dalam metode SEM maka diperlukannya metode bootstrap. Bootstrap merupakan metode berbasis resampling dari pengambilan sample asli dan pengembalian data dengan harapan sampel dapat mewakili populasi.

Hasil uji normalitas menunjukan terdapat indikator yang tidak terdistribusi normal karena nilai $P$-value dalam skewness dan kurtosis $<0,05$ yaitu Nach1, Nach2, BP4, BP5 dan BP6. Dengan adanya indikator yang terdistribusi tidak normal tersebut, peneliti menggunakan fasilitas normal scores pada software LISREL untuk mentranformasikan data menjadi normal. Setelah menggunakan fasilitas normal scores semua indikator bertransformasi menjadi normal ditunjukan pada nilai $P$-value dalam skewness dan kurtosis $>0,05$

Hasil uji validitas menunjukan variabel Need for Achievement (X), Budgetary Participation (Y), dan Job Performance (Z) memiliki indikator dengan nilai standard loading factors $<0,50$ yang menandakan tidak dapat menunjukan kevalidannya sebagai suatu alat ukur maka indikator tersebut dihapuskan. Indikator tersebut adalah Nach4, Nach5, BP1, BP2, dan JP1. Setelah dilakukan pengujian ulang, hasilnya masih terdapat indikator yang memiliki nilai standard loading factors $<0,50$ yaitu Nach1, maka variabel tersebut dihapuskan dan dilakukan pengujian kembali. Setelah dilakukan pengujian ulang seluruh 
indikator telah lolos uji validitas dengan nilai standard loading factors $<0,50$.

Hasil uji reliabilitas yang baik memiliki nilai construct reliability $>0,70$ dan nilai variance extracted $>0,50$. Hasil menunjukan nilai construct reliability variabel need for achievement $(0,78)$, budgetary participation $(0,89)$, dan job performance $(0,87)$. Sedangkan nilai variance extracted variabel need for achievement $(0,65)$, budgetary participation $(0,68)$, dan job performance $(0,50)$. Dengan demikian responden menjawab pertanyaan dengan konsisten dan konstruk reliabel atau dapat diandalkan.

Hasil uji kecocokan keseluruhan model menggunakan beberapa ukuran goodness of fit indices (GOFI). Adapun hasil pengujian tersebut dapat ditunjukan pada tabel sebagai berikut :

Tabel 1.

Evaluasi Goodness of Fit Indices

\begin{tabular}{cccc}
\hline $\begin{array}{c}\text { Ukuran } \\
\text { GOF }\end{array}$ & $\begin{array}{c}\text { Target Tingkat } \\
\text { Kecocokan Model }\end{array}$ & $\begin{array}{c}\text { Hasil Estimasi } \\
\text { Model }\end{array}$ & Tingkat Kecocokan Model \\
\hline Chi-Square & p-value $>0.05$ & 0.018 & Bad Fit \\
RMR & RMR $<0.05$ & 0.015 & Good fit \\
RMSEA & RMSEA $<0.08$ & 0.070 & Good fit \\
GFI & GFI $>0.90$ & 0.91 & Good fit \\
NFI & NFI $>0.90$ & 0.95 & Good fit \\
NNFI & NNFI $>0.90$ & 0.97 & Good fit \\
CFI & CFI $>0.90$ & 0.98 & Good fit \\
IFI & IFI $>0.90$ & 0.98 & Good fit \\
RFI & RFI $>0.90$ & 0.92 & Good fit \\
\hline
\end{tabular}

\section{Pengujian Hipotesis}

Besarnya pengaruh antar variabel laten dengan melihat nilai koefisien jalur yang terbentuk. Sedangkan, pengujian signifikansi berdasarkan nilai $t_{\text {hitung }}$ sebesar 1,96 . Jika nilai $t_{\text {hitung }}$ lebih besar dari $t_{\text {tabel }}$ maka ha dapat diterima dan ho ditolak, begitupun sebaliknya.

Berdasarkan hasil perhitungan dapat disimpulkan bahwa hipotesis 1 diterima, nilai $t_{\text {hitung }}$ 3,49 lebih besar dibanding $t_{\text {table }}$ 1,96 dan nilai koefisien estimasi 0.32 . Karena nilai nilai $t_{\text {hitung }}$ lebih besar dibanding $t_{\text {table, maka }}$ diputuskan untuk menerima $\mathrm{H}_{1}$ dan $\mathrm{Ho}$ ditolak.

Hipotesis 2 diterima, nilai $t_{\text {hitung }} 3,03$ lebih besar dibanding table 1,96 dan nilai koefisien estimasi 0,31. Karena nilai thitung lebih besar dibanding table, maka diputuskan untuk menerima $\mathrm{H}_{2}$ dan Ho ditolak.

Hipotesis 3 diterima, dapat dilihat nilai $t_{\text {hitung }} 4,28$ lebih besar dibanding $t_{\text {table }} 1,96$ dan nilai koefisien estimasi 0,56 . Karena nilai $t_{\text {hitung }}$ lebih besar dibanding $t_{\text {table }}$ maka diputuskan untuk menerima $\mathrm{H}_{3}$ dan $\mathrm{Ho}$ ditolak.

Hipotesis 4 diterima, dapat dilihat nilai $t_{\text {hitung }}$ 2,65 lebih besar dibanding $t_{\text {table }} 1,96$ dan nilai koefisien estimasi 0,32 . Karena nilai $t_{\text {hitung }}$ lebih besar dibanding $t_{\text {table, maka }}$ diputuskan untuk menerima $\mathrm{H}_{4}$ dan $\mathrm{Ho}$ ditolak.

\section{Pengaruh Need for Achievement terhadap Job Performance}

Berdasarkan hasil pengujian diputuskan menerima HI yang artinya need for achievement berpengaruh positif dan signifikan terhadap job performance. Hal tersebut menandakan semangkin tingginya kebutuhan untuk berprestasi pegawai Biro Perencanaan dan Keuangan Setjen Kemenkeu RI, maka semangkin tinggi pula kinerja mereka.

Tingginya kebutuhan untuk berprestasi tersebut dapat dilihat dan terbentuk dari latar belakang pendidikan pegawai Biro Perencanaan dan Keuangan Setjen Kemenkeu 
RI, dimana sebagian besar berasal dari Politeknik Keuangan Negara STAN. Dimana PKN STAN menerapkan standar tinggi dalam sistem pendidikannya. Contohnya adalah mekanisme rekuitmen dengan standar tinggi dan penerapan drop out bagi siswa yang tidak memenuhi syarat IPK yang diterapkan setiap semester. Oleh karena itu dapat memungkinkan pegawai membawa budaya saat pendidikannya yang memiliki motivasi berkompetensi dengan sebuah standar keunggulan.

Pegawai dengan memiliki kebutuhan untuk berprestasi akan dapat bekerja lebih aktif dan berupaya untuk menghasilkan pekerjaan lebih baik dibanding orang lain, karena mereka akan berusaha dalam mendapat suatu penghargaan dan pengakuan atas hasil prestasi kinerja yang menimbulkan suatu kebanggaan tersendiri atas pemenuhan kebutuhan tersebut. Maka dengan sendirinya mereka termotivasi untuk meningkatkan kinerja yang dihasilkan.

Oleh karena itu mengembangkan movivasi untuk berprestasi dalam meningkatkan kinerja pegawai menjadi salah satu faktor yang penting. Karena dengan adanya faktor pemacu, maka pegawai akan termotivasi meningkatan kinerja lebih baik dari pada sebelumnya yang mengarah pada keberhasilan organisasi.

Hasil penelitian ini didukung penelitian sebelumnya yang dilakukan oleh Hernanda \& Mukzam (2018), Lestariningsih (2017) dan Utomo et.al (2017) menyatakan bahwa need for achievement berpengaruh positif dan signifikan terhadap job performance. Namun hasil ini tidak sejalan dengan penelitian yang dilakukan oleh Aziti (2019) yang menunjukan need for achievement tidak berpengaruh signifikan terhadap job performance.

\section{Pengaruh Need for Achivement terhadap Budgetary Participation}

Berdasarkan hasil pengujian diputuskan menerima $\mathrm{H} 2$ artinya need for achievement berpengaruh positif dan signifikan terhadap budgetary participation.

Hal tersebut menandakan bahwa semangkin tingginya kebutuhan berprestasi pegawai Biro Perencanaan dan Keuangan Setjen Kemenkeu RI maka semangkin tinggi pula partisipasi mereka dalam proses penyusunan anggaran.

Tingginya kebutuhan berprestasi, menjadikan pegawai berupaya untuk mendapatkan informasi yang relavan dengan pekerjaan melalui penyusunan anggaran secara partisipatif. Selain itu tingginya kebutuhan berprestasi dapat itu memicu semangat kerja pegawai, sehingga pegawai akan berkontribusi dalam banyak dalam mengembangkan dan penyampaian ide kreatif yang dimiliki pada proses partisipasi anggaran. Hal tersebut dapat dijelaskan bahwa pegawai memiliki kebutuhan berprestasi lebih fleksibel dalam mencari informasi secara terperinci untuk membantu mereka dalam mengejar keunggulan.

Pegawai dengan tingkat kebutuhan berprestasi yang tinggi biasanya ingin mengetahui suatu feedback. Feedback tersebut membantu pegawai untuk mengetahui seberapa baik mereka bertanggung jawab melaksanakan tugasnya, maka untuk mendapatkan feedback baik pegawai akan berpartisipasi aktif dalam penyusunan anggaran, harapannya pegawai dapat mencapai tujuan yang ditetapkan sesuai dengan kemampuan yang dimiliki.

Hasil penelitian ini didukung penelitian sebelumnya yang dilakukan oleh Djalil et.al (2017) dan Wiguna (2017) yang menyatakan bahwa konsep motivasi kerja need for achievement berpengaruh positif dan signifikan terhadap budgetary participation. Namun hasil ini tidak sejalan dengan penelitian yang dilakukan oleh Ernawati (2017) dimana motivasi kerja untuk memenuhi kebutuhan prestasi tidak berpengaruh signifikan terhadap penganggaran partisipasi.

\section{Pengaruh Budgetary Participation terhadap Job Performance}

Berdasarkan hasil pengujian diputuskan menerima $\mathrm{H} 3$ artinya budgetary participation berpengaruh positif dan signifikan terhadap job performance. Hal tersebut menandakan semangkin tinggi tingkat partisipasi pegawai Biro Perencanaan dan Keuangan Setjen Kemenkeu RI saat penyusunan anggaran, maka akan meningkatkan kinerja pegawainya.

Agar mendapatkan anggaran yang diputuskan lebih realistis dan sesuai dengan 
tujuan organisasi. Maka sangat membutuhkan kerjasama pegawai bawahan dan atasan untuk berpartisipasi memberikan kontribusi mereka dalam menyusunan anggaran. Karena pada dasarnya pegawai bawahan lebih banyak memiliki informasi dari pada atasan mereka, temasuk memperhitungkan alokasi sumberdaya yang dibutuhkan dan dengan melakukan hal tersebut dapat mengurangi resiko alokasi yang tidak efisien sehingga anggaranpun dapat lebih akurat dan andal yang memungkinkan efisiensi alokasi sumberdaya.

Pegawai diberikan kesempatan mengumpulkan dan bertukar informasi dalam membuat keputusan. Hal tersebut memberikan suatu kepuasan atas keterlibatan mereka dalam sebuah keputusan saat proses perencanaan anggaran, dari pada anggaran yang telah ditetapkan oleh atasan. Ketika suatu tujuan telah dirancang dengan partisipatif disetujui oleh pimpinan, dengan melibatkan pegawai lebih rendah maka mereka merasa aspirasinya dihargai.

Sehingga pegawai bersungguh-sungguh mencapai tujuan yang telah ditetapkan, hal tersebut dikarenakan pegawai memiliki sebuah tanggung jawab dan berkomitmen tinggi untuk mencapai tujuan tersebut. Pada akhirnya menciptakan motivasi dalam berkinerja lebih baik akibat suatu perasaan anggaran yang dibuat sebagai hasil keterlibatan mereka.

Hasil penelitian ini didukung penelitian sebelumnya yang dilakukan oleh Myint et. Al (2019), Karakoc \& Ozer (2016) dan Wiguna et.al (2017) yang menyatakan bahwa penganggran partisipasi berpengaruh positif dan signifikan terhadap job performance. Namun hasil ini tidak sejalan dengan penelitian yang dilakukan oleh Andison \& Augustin (2017) dimana budgetary participation tidak berpengaruh signifikan terhadap job performance.

\section{Pengaruh Need for Achivement terhadap Job Performance melalui Budgetary Participation}

Berdasarkan hasil pengujian diputuskan menerima $\mathrm{H} 3$ artinya need for achievement berpengaruh positif dan signifikan terhadap job performance melalui budgetary participation. Hal tersebut memperlihatkan pegawai Biro Perencanaan dan Keuangan Setjen Kemenkeu RI memiliki kebutuhan untuk berprestasi yang tinggi dengan berusaha mencari informasi secara terperinci untuk membantu mengejar keunggulan melalui partisipasi penyusunan anggaran dan secara tidak langsung meningkatkan kinerja lebih tinggi.

Karakteristik individu yang memiliki kebutuhan untuk prestasi yang tinggi berharap memperoleh feedback atau tanggapan atas pelaksanaan tugasnya. Untuk mendapatkan feedback yang baik memicu semangat kerja pegawai, sehingga akan berkontribusi banyak dalam mengembangkan, menyampaikan ide kreatif yang dimiliki dan berusaha mencari informasi yang relavan mengenai pekerjaan pada proses partisipasi anggaran.

Karena saat proses partisipasi anggaran pegawai dapat memiliki informasi untuk mengkontrol pekerjaan mereka dalam mendapatkan umpan balik atau penilaian secara spesifik seberapa baik mereka dalam melakukan pekerjaan atau bertanggung jawab ditargetkan, seperti upaya, arahan atau strategi yang dilakukan sesuai dengan kemampuan yan dimiliki. Sehingga secara tidak langsung memiliki motivasi untuk meningkatkan kinerja sesuai dengan tujuan standar yang telah ditetapkan.

\section{Kesimpulan, Keterbatasan dan Implikasi Hasil Penelitian}

Need for achievement berpengaruh positif dan signifikan terhadap job performance. Semakin besar kebutuhan pegawai untuk berprestasi akan berupaya menghasilkan pekerjaan lebih baik. Hal ini didasari oleh suatu pemikiran kebutuhan untuk berprestasi dapat memicu semangat untuk berkerja lebih baik dari pada sebelumnya atau orang lain.

Need for achievement berpengaruh positif dan signifikan terhadap budgetary participation. Pegawai memiliki kebutuhan berprestasi yang tinggi dengan berupaya mendapatkan informasi yang relavan dengan pekerjaan melalui partisipasi dalam penyusunan anggaran, untuk memastikan target dapat dicapai sesuai dengan kemampuannya.

Budgetary participation berpengaruh positif dan signifikan terhadap job performance. Dengan ikut berkontrbusi dalam 
proses penetapan anggaran, maka pegawai lebih memahami tujuan dan merasa anggaran yang dibuat sebagai hasil dari keterlibatan mereka. Dengan demikian pegawai akan termotivasi untuk berkinerja lebih baik dalam mencapai tujuan yang telah ditargetkan.

Need for achievement berpengaruh positif dan signifikan terhadap job performance melalui budgetary participation. Indvidu dengan kebutuhan prestasi tinggi akan berupaya mencari informasi terkait pekerjaan melalui partisipasi anggaran karena memiliki keinginan memperoleh pengakuan atau feedback yang baik atas apa yang ditargetkan. Secara tidak langsung akan meningkatkan kinerja pegawai untuk memenuhi kebutuhan tersebut.

Penelitian ini memiliki keterbatasan dan kelemahan antara lain responden yang berkontribusi hanya terbatas pada eselon 4 dan pelaksana/staf pada Biro Perencanaan dan Keuangan Sekretariat Jenderal Kementrian Keuangan, sehingga hasil tidak dapat digeneralisasi pada organisasi lainnya. Selain itu pengukuran job performance menggunakan self ranting scale yang mengakibatkan responden cenderung mengukur kinerjanya lebih tinggi dari pada yang sebenarnya.

Adapun beberapa saran yang dapat disampaikan untuk penelitian selanjutnya yaitu peneliti selanjutnya diharapkan dapat memperluas obyek penelitian dari beberapa organisasi yang lebih besar, penelitian selanjutnya diharapkan selain menggunakan kuesioner juga dapat melakukan wawancara untuk mengatasi bias atas pertanyaan kuesioner, dan peneliti selanjutnya diharapkan dapat menambah variabel lainnya yang dapat mempengaruhi job performance.

\section{Daftar Pustaka}

Acquah, Andrews. (2017). Implication of The Achivement Motivation Theory for School Management in Ghana: A Literature Review. Research on Humanities and Social Sciences 7(5): 1015.

Al-Omari, K., \& Okasheh, H. (2017). The Influence orf Work Environment on Job performance: A Case Study of Engineering Company in Jordan.
International Journal of Applied Engineering Research 12(24): 1554415550.

Andison., \& Augustine, Y. (2017). Partisipasi Anggaran, Kepuasan Kerja dan Kinerja Manajerial: Studi Pada Bisnis Keluarga Pempek di Kota Palembang. Jurnal Bisnis dan Manajemen 7(1): 73-82.

Aziti, T. M. (2019). Pengaruh Motivasi Kekuasaan, Motivasi Afiliasi, dan Motivasi Berprestasi Terhadap Kinerja Karyawan PT.X. Management and Entrepreneurship Journal. 2(2):71-82.

Chong, Vincent, K., \& Khudzir, N. (2018). The Effect of Mutual Monitoring and Need for achievement on Budgetary Slack in a Team-Based Envoronment. Advances in Accounting Beharvioral Research 21: 1-19.

Djalil, M. A., Indriani, M., \& Muttaqin. (2017). The Influence of Organizational Commitment and Motivation in the Relationship between Budget Participation and Managerial Performance (Empirical Study on Provincial Government Agencies (SKPA) of Aceh Province, Indonesia). Broad Research in Accounting, Negotiation, and Distribution 8(1): 12-24.

Ernawati, N. (2017). Pengaruh Partisipasi Anggaran Terhadap Kinerja Manajerial Dengan Motivasi Kerja Sebagai Variabel Pemoderasi (Studi Kasus SKPD Kabupaten Pati). Jurnal Akuntansi Indonesia 6(2): 141-156.

Hernanda, D., \& Mukzam, M. D. (2018). Pengaruh Kebutuhan Prestasi, Kekuasaan, dan Afiliasi terhadap Kinerja Karyawan (Studi pada Karyawan PT PLN [PERSERO] Area Kediri Distribusi Jawa Timur). Jurnal Administrasi Bisnis 62(1): 218-223.

Husniyawati, Y. R., \& Wulandari, R. D. (2016). Analisis Motivasi Terhadap Kinerja Kader Posyandu Berdasarkan Teori Victor Vroom. Jurnal Administrasi Kesehatan Indonesia 4:(2) 126-135.

Kar, Bulbul., \& Mishra, Biswadeep. (2016). A Literature Review on Occupational 
Streess and Job performance. International Journal of Engineering and Management Research 6(1): 402-407.

Karakoc, E. Y., \& Ozer, G. (2016). The Budget-Related Antecedents of Job Performance. International Journal of Research in Business \& Social Science 5(3): 38-53.

Lestariningsih, M. (2017). Self efficacy and Achivement Motivarion on Performance with perceived Organizational Support Moderation (A tudy on private university lecturer with "A" Accreditation Kopertis Region VII East Java). Advences in Intelligent Systems Research 131: 81-85.

Lloyd, R., \& Mertens, D. (2018). Expecting More Out of Expectancy Theory: History Urges Inclusion of the Social Context. International Management Review 14(1): 28-43.

Meirina, Elsa., \& Afdalludin. (2018). Pengaruh Partisipasi Anggaran, Informasi Asimetris dan Budget Emphasis Terhadap Slack Anggaran. Jurnal Pundi 2(3): 261272.

Mensah, E. B. K., \& Tawiah, K. A. (2016). Employee Motivation and Work Performance: A Comparative Study of Mining Companies in Ghana. Journal of Industrial Engineering and Management 9(2): 255-309.

Murgijanto, E. (2017). Pengaruh Kebutuhan Prestasi, Kebutuhan Afiliasi Dan
Kebutuhan Kekuasaan Terhadap Semangat Kerja Dosen Pada Sekolah Tinggi Ilmu Ekonomi Ama Salatiga. Jurnal Ilmiah Among Makarti 10(19): 3551.

Myint, Yu. Yu., Mithunchakravarthy, Divya., Raju, Valliappan., \& Bhaumik, Amiya. (2019). Budget Participation and Employees' Motivation in Myanmar Private Commercial Banks. International Journal of Innovative Technology and Exploring Engineering 8: 573-578.

Rosada, M. A., Putro, S. C., \& Putranto, H. (2018). Effect of Self Regulatort Learning, Personal Goal Setting And Perceptions of The Teaching Professionon On Literacy Of Vocational Teachers. Jurnal Pendidikan Teknologi dan Kejuruan 24(2): 286-294.

Utomo, J., Nanere, M., \& Sutono. (2017). The Effect Achievement Motivation, Leadership Character and Internal Culture Towards Employee's Performance a Case Corporate from Indonesia. Jurnal of Applied Management 15(1): 1-9.

Wiguna, L. Y. P., Sukartha, I. M., \& Astika. I. B. P. (2017). Pengaruh Partisipasi Penyusunan Anggaran Pada Kinerja Aparat Pemerintah Daerah Dengan Budaya Organisasi, Motivasi, dan Gaya Kepemimpinan Sebagai Variabel Moderating. E- Jurnal Ekonomi dan Bisnis Universitas Udayana 6(8): 30413070 . 
Yusar Sagara, Indah Permatasari, Roebiandini Soemantri: Pengaruh Need Achievement Terhadap Job Performance dengan Budgetary Participation sebagai Variabel Intervening 